\title{
PERSEPSI KEPUASAN MASYARAKAT TERHADAP KUALITAS LAYANAN PENDIDIKAN MADRASAH BINAAN KECAMATAN BRINGIN KABUPATEN SEMARANG TAHUN 2021
}

\author{
NUR SA'IDU \\ Pengawas Madrasah Kementerian Agama Kabupaten Semarang \\ Email. masnursaidu68@gmail.com
}

\begin{abstract}
ABSTRAK
Tujuan penelitian ini adalah untuk mengetahui dan mendiskrpsikan persepsi tingkat kepuasan masyarakat pengguna jasa pendidikan terhadap kulaitas layanan Pendidikan serta dimensi-dimensi yang yang berpengaruh terhadap kepuasan orang tua siswa di Madrasah binaan kecamatan Bringin Kabupaten Semarang. Pengukuran terhadap kualitas Pendidikan menggunakan SERVQUAL yang meliputi dimensi Tangible, Reliability, Responsevenes, Assurance, Empathy. Metode yang digunakan dalam penelitian ini adalah metode deskriptip dengan teknik survey secara Daring (dalam jaringan/online). Jenis penelitian ini adalah penelitian ex post de Facto yaitu tidak perlu memberikan perlakuan lagi terhadap variabel bebas tapi tinggal melihat efeknya pada varibel terikat, dengan menggunakan pendekatan historis ,penelitian korelasional, dan penelitian kausal dengan korelasi. Teknik pengambilan sample menggunakan stratified sampling random berdasarkan jumlah orang tua siswa pada madrasah binaan.Instrumen penelitian yang digunakan adalah Angket dengan bentuk pilihan yang menggunakan skala linkert 5 alternatif jawaban dan sebagai data pembanding menggunakan wawancara dengan komite dan guru kelas 6, kepala madrasah. Hasil yang dtemukan dalam penelitian ini tentang persepsi masyarakat terhadap madrasah binaan adalah sebagai berikut : dimensi Tangible 69,47 \%, Reliability 75,67\%., Responsevenes 70,32\%., Assurance 72,48\%, Empahty 76,37\%.
\end{abstract}

Kata Kunci : Kepuasan Masyarakat, Kualitas layanan, SERVQUAL

\section{PENDAHULUAN.}

Dalam dunia pendidikan mengukur tingkat kepuasan orang tua dan siswa terhadap layanan pendidikan menjadi hal yang sangat penting untuk mengetahui seberapa baik layanan yang telah diberikan oleh sekolah. Sekolah sebagai lembaga penyedia jasa pendidikan perlu memiliki inisiatif untuk meningkatkan kepuasan pelanggan karena pendidikan merupakan proses sirkuler yang saling mempengaruhi dan berkelanjutan (Bukhori, 2008).

Peningkatan kualitas pelayanan merupakan salah satu isu penting dalam lembaga pendidikan. Hal ini terjadi karena di satu sisi tuntutan masyarakat terhadap perbaikan kualitas layanan pendidikan mengalami peningkatan dari tahun ke tahun. Pelayanan pendidikan dianggap berkualitas apabila pelayanan tersebut dapat memenuhi kebutuhan masyarakat terutama sebagai pengguna pelayanan tersebut. Dalam lembaga pendidikan tinggi seperti halnya universitas, sekolah tinngi dan akademi, kualitas pelayanan pendidikan dianggap berkualitas tentunya apabila pelayanan pendidikan yang diberikan mampu memenuhi kebutuhan mahasiswa dan kebutuhan masyarakat luas sebagai pengguna output lembaga pendidikan (Irma, 2013).

Persaingan kualitas pelayanan lembaga pendidikan saat ini sangat tinggi, agar lembaga pendidikan dapat bertahan dan berkembang, pihak lembaga harus proaktif dan memberikan pelayan yang berkualitas kepada konsumennya. Dengan cara memahami persepsi konsumen mengenai pelayanan dalam di lembaganya serta mampu menerapkan apa yang diinginkan oleh konsumen. Lembaga tersebut akan mampu bertahan dan unggul dalam kompetisi lembaga di era globalisasi.

Perhatian sekolah saat ini terhadap kepuasan pelanggan maupun ketidak puasan pelanggan saat ini semakin besar. Persaingan sangat ketat dimana semakin banyak sekolah yang terlibat dalam pemenuhan kebutuhan dan keinginan siswanya menyebabkan setiap sekolah dituntut mampu menempatkan pelayanan jasa pendidikan berorientasi pada kepuasan dalam bidang Pendidikan untuk mencapai prestasi tinggi dalam membentuk citra/image sekolah yang unggul dan baik.

Dalam layanan sekolah saat ini telah distandarisasi oleh pemerintah melalui Peraturan 


\section{EDUCATIONAL : Jurnal Inovasi Pendidikan dan Pengajaran \\ Vol. 1 No. 3 Agustus 2021 e-ISSN : 2775-2593 | p-ISSN : 2775-2585}

Menteri Pendidikan Nasional Republik Indonesia Nomor 23 tahun 2013 tentang standar layanan minimal di sekolah kabupaten/kota. Artinya sekolah harus memberikan layanan sebaik mungkin kepada pelanggannya termasuk peserta didik agar penilaian yang diberikan oleh peserta didik dapat baik pula. Dengan hal ini, maka sekolah perlu melakukan perbaikan dalam pengelolaan layanan sebagai upaya untuk meningkatkan rasa nyaman di sekolah serta peningkatan kesadaran dalam pendidikan.

Citra akan terbentuk dari bagaimana lembaga pendidikan melaksanakan kegiatan operasionalnya, yang mempunyai landasan utama dalam segi pelayanan. Menurut Fandy Ciptono (2001:17) perspektif kualitas terhadap kepuasan pelanggan pada hakekatnya adalah bahwa pelanggan merupakan penilaian akhir dari kualitas, sehingga prioritas utama dalam jaminan kualitas adalah memiliki piranti yang handal dan sahih mengenai penilaian pelanggan (siswa, orang tua/masyarakat) terhadap sekolah.

Dari kenyataan diatas nampak bahwa kepuasan kepuasan siswa maupun orang tua merupakan faktor penting untuk bertahan dalam persaingan dan mempertahankan citra baik sekolah sebagai serta membangun loyalitas siswa maupun orang tua/masyarakat pada lembaga tersebut. senada dengan hal tersebut sebagaiman dungkapkan dalam hasil penelitian Ali. et al (2016:72) hasil study dari tiga Universitas Negeri malsyia melalui 400 kuisioner menemukan bahwa lima dimensi kualitas layanan pendidikan tinggi berpengaruh pada tingkat kepuasan mahasiswa dan citra kelembagaan secara simultan mempengaruhi loyalitas mahasiswa.

Banyak cara yang dapat dilakukan untuk menarik minat publik dan membentuk citra lembaga pendidikan, baik melalui daya tarik fisik lembaga seperti letak lokasi yang strategis dan mudah dijangkau, bangunan yang nyaman, kualitas layanan, fasilitas berstandar, serta harga terjangkau atau daya tarik yang bersifat akademis seperti reputasi, prospek, keragaman pilihan studi, standar kelulusan dan kegiatan-kegiatan penunjang lainnya. Maka dari itu sekolah yang baik adalah sekolah yang berkualitas. Kualitas adalah keseluruhan ciri serta sifat dari suatu produk atau layanan yang berpengaruh pada kemampuannya untuk memuaskan kebutuhan yang dinyatakan atau tersirat (Ronita, 2018).

Masyarakat sebagai pelanggan sekolah (siswa, orang tua, serta pihak-pihak terkait) perlu diyakini bahwa sekolah yang akan dipilih adalah sekolah yang memberikan layanan yang relevan sesuai dengan kebutuhan dan tuntutan zaman. Namun saat ini banyak lembaga pendidikan saling berlomba untuk memperoleh siswa dengan menunjukkan eksistensi sekolah lewat label internasional, akreditasi, prestasi yang diraih, tingkat kelulusan yang tinggi, fasilitas sarana dan prasarana yang memadai dan mendukung, program unggulan, dan layanan pendidikan lainnya yang membedakannya dari sekolah lainnya. Akan tetapi disisi lain siswa dan orang tua memiliki kebebasan untuk memilih sekolah yang menurut penilaian mereka memiliki kualitas yang baik (Nana, 2015).

Maka dari itu suatu lembaga sekolah harus memiliki visi dan misi, serta strategi manajemen pendidikan secara utuh dan berorientasi pada peningkatan kualitas layanan. Strategi ini merupakan usaha sistematis dan terkoordinasi untuk secara terus menerus memperbaiki kualitas layanan, sehingga fokusnya diarahkan kepada pelanggan, dalam hal ini yang dimaksud adalah peserta didik, orang tua peserta didik, pemakai lulusan, guru, karyawan, pemerintah, dan masyarakat. Sedikitnya terdapat lima sifat layanan yang harus diwujudkan oleh lembaga pendidikan agar pelanggan puas, yakni layanan yang sesuai dengan yang dijanjikan (reliability), mampu menjamin kualitas pembelajaran (assurance), iklim sekolah yang kondusif (tangible), memberikan perhatian penuh kepada peserta didik (emphaty), serta cepat tanggap terhadap kebutuhan peserta didik (responsivenes) (Mulyasa, 2011).

Hasil Survey pendahuluan yang dilakukan di Madrasah binaan terhadap 13 Kepala Madrasah Ibtidaiyah Kecamatan Bringin Kabupaten Semarang secara rata-rata dengan simpulan awal bahwa persoalan layanan madrasah tidak bisa maksimal antara lain disebabakan adanya pendidik merangkap menjadi tenaga kependidikan, ( tenaga keoperatoran) yang menyebabkan pendidik sering abstain. Temuan awal ini menarik peneliti untuk mengadakan penelitian tentang kulaitas layanan madrasah terhadap kepuasan pelanggan. 


\section{METODE PENELITIAN}

Penelitian ini menggunakan pendekatan kuantitatif dengan teknik peneltian deskriptif analitis. Penelitian ini dilakukan di 13 Madrasah binaan Kecamatan Bringin Kabupaten Semarang, waktu penelitian mulai Agustus 2021.Subyek Penelitian terdiri dari populasi 351 Orang tua wali murid madrasah binaan kelas 6 dengan sample secara propisional 182 wali murid. Pengumpulan data menggunakan survey dilakukan dengan angket/kuisioner dalam bentuk pertanyaan tertutup melalui Google Form yang berisikan beberapa pertanyaan dengan alternatif jawaban yang mewakili realitnya. Selanjutnya kuisiner/angket diisi oleh responden (wali murid) terkumpul di Google Spreed Sheet.

Angket yang digunakan dalam mengumpulkan data penelitian ini adalah angket tertutup dengan skala penilaian yang digunakan rating scale. Jawab setiap item terdiri dari 5 (lima) alternatif jawaban dengan setiap item dinyatakan dari sangat positif sampai dengan negatif. Bobot penilian mencakup nilai tertinggi 5 dan nilai terndah 1.Responden dapat memilih alternatif jawaban dari setiap butir penyataan yang ditanyakan sesuai keadaan sebenarnya. Pengukuran kualitas layanan Pendidikan dikembangkan berdasarkan 5 (Lima) Dimensi yang dikembangkan oleh (Mulyasa, 2011) yaitu : Tangible (bukti fisik), Realibility ( keandalan), Responsiveness (ketanggapan), Assurance ( jaminan dan kepastian), Empathy ( empati) terhadap kepuasan orang tua (wali murid). Pengujian isntrumen peneleitian dengan melakukan uji validitas dan reliabilitas, Uji validitas menggunakan validitas isi/konstruk dan validitas butir menggunakan korelasi product moment.

\section{HASIL DAN PEMBAHASAN.}

Persepsi masyarakat secara umum dapat diartikan sebagai anggapan atau pemberian makna. Ivancevich et.al (2003) menjelaskan persepsi adalah proses melibatkan pemilihan, pengorganisasian dan interpretasi dari faktor-faktor lingkungan, bentuk, orang dan stimulus yang mereka amati. Sedangkan masyarakat menurut Kuncoroningrat mendefinisikan kesatuan-kesatuan hidup manusia yang berinteraksi menurut sistem adat istiadat tertentu yang bersifat kontinyu dan yang terikat suatu rasa identitas bersama. Orang tua/wali murid adalah komponen keluarga yang terdiri dari ayah dan ibu, dan merupakan hasil dari sebuah ikatan yang sah yang dapat membentuk sebuah keluarga. Orang tua memilki tanggung jawab untuk mendidik, mengasuh dan membimbing anak-anaknya untuk mencapai tahapan tertentu yang menghantarkan anak untuk siap dalam kehidupan bermasyarakat.

Dari definisi diatas dapat ditarik kesimpulan bahwa persepsi orang tua/masyarakat dapat diartikan sebagai pemberian arti atau makna oleh orang melalui penginderaan terhadap lingkunngan atau obyek yang diinderakan, dimana lingkungan tersebut mencakup penafsiran obyek yang diinderakan, dimana lingkungan mencakup penafsiran mengenai gambaran terhadap keadaan yang diamati. Faktor yang mempengaruhi persepsi seseorang dalam memandang suatu masalah adalah sikap, keadaan mental, keadaan jiwa dan diri seseorang individu untuk bereaksi terhadap lingkungan masyarakat baik lingkungan alamiah maupun secara fisik. Sikap dipengaruhi oleh banyak faktor antara lain latar belakang pendidikan, pengaruh lingkungan sekitar, pengalaman pribadi dan individu.Strategi pendidikan adalah tentang posisi kompetitip yang membedakan diri di mata siswaatau klien tentang hal yang dapat menambah nialai melalui kombinasi kegiatan berbeda yang diguanakan oleh pesaing (Amesi dalam Wibisono, 2017). Strategi agar lembaga pendidikan tetap exis dengan meningkatkan kualitas pelayanan. Peningkatan kualitas layanan ditekankan pada pemenuhan keinginan pelanggan sebagai salah satu strategi pemasaran jasa pendidikan.

Layanan merupakan aktivitas atau kegiatan yang menawarkan manfaat untuk dijual dengan tujuan tertentu dan tidak terwujud pada dasarnya serta atau diartikan sebagai aktivitas utama pelengkap yang secara tidak langsung menghasilkan produk fisik, yaitu benda/barang bagian dari transaksi antara pembeli dan penjual. Dalam arti layanan ini menekankan pada bentuk fisik benda berujud. Pengertian lain layanan adalah produk yang tidak berwujud yang ditawarkan untuk memuaskan pelanggan.

Persepsi tentang kualitas pelayanan pendidikan dibutuhkan untuk menentukan apakah pelayanan Madrasah binaan kecamatan Bringin Kabupaten Semarang telah sesuai dengan harapan orang tua/wali siswa sebagai pelanggan yang mempertaruhkan pendidikan anaknya pada lembaga 
tersebut. Jika pelayan Pendidikan yang diberikan kepada anak/siswa sesuai harapan yang diinginkan orang tua wali murid maka pelayanan tersebut dianggap pelayanan yang baik.Kualitas merupakan ukuran yang digunakan untuk menentukan sesuatu berupabarang atau jasa. Dalam Pelayan penyelenggaraan pendidikan, peningkatan pelayan harus selalu dapat ditingkatkan secara berkesimbangun.

Kualitas pelayanan dibutuhkan untuk menentukan apakah pelayanan tersebut sesuai dengan yang diharapkan oleh masyarakat atau tidak. Jika pelayanan terhadap masyarakat tersebut baik atau sesuai dengan yang diinginkan masyarakat maka pelayanan tersebut memiliki kualitas pelayanan yang baik. Kualitas merupakan suatu ukuran yang digunakan untuk menentukan sesuatu yang berupa barang ataupun jasa. Dalam penyelenggaraan pelayanan publik, peningkatan pelayanan harus terus ditingkatkan guna terciptanya kepuasan pelanggan (masyarakat).

Kepuasan pelanggan adalah perbandingan antara harapan yang diinginkan pelanggan tentang layan pendidikan dengan apa yangpelanggan rasakan setelah mendapatkan pelayanan. Menurut Parasuraman,et al (1985) bahwa kualitas pelayanan merupakan aktifitas yang dapat meningkatkan kepuasan. Dalam dunia pendidikan kepuasan pelanggan dapat diamati dari perilaku siswa yang melakukan kegiatan rutin. Loyalitas mengacu pada perilaku yang relatif stabil dalam jangka panjang dari unit-unit pengambil keputusan untuk melakukan kegiatan secara terus menerus terhadap progam lembaga pendidikan yang dipilih (Rusdiana, 2015:266).

Kepuasan pelanggan akan mendorong pada loyalitas pelanggan yang merupakan tingkat perasaan sesorang setelah membandingkan kinerja yang dirasakan dengan harapan dari sesorang atau kelompok yang membeli barang atau jasa dalam hal ini adalah adalah jasa pelayan pendidikan di madrasah. Untuk mengukur tingkat kepuasan orang tua terhadap pelayanan jasa pendidikan madrasah dengan menggunakan model SERQUAL ( Service Quality) yang terdiri dari 5 dimensi yaitu : Tangible (Bukti Fisik), Realibilty (Kehandalan), Responsiveness (Responsif), Assurance (jaminan), Empaty (Empati). Adapaun hasil persepsi dari masing-masing dimensi tersebut sebagaimana hasil dari survey angket sebagaiman dijelakan berikut :

\section{Persepsi Orang tua siswa terhadap kepuasan pelayanan Pendidikan di madarsah binaan pada Dimensi Tangible (bukti fisik)}

Tabel 1. Persepsi Kepuasan orang tua pada Dimensi Tangible

\begin{tabular}{|c|c|c|c|}
\hline N0. & Tangible ( Bukti Fisik) & Nilai & Kategori \\
\hline 1 & Gedung Sekolah & $69,78 \%$ & $\begin{array}{l}\text { Cukup } \\
\text { Memuaskan }\end{array}$ \\
\hline 2 & Ruang kelas terjaga kerapiannya & $77,00 \%$ & Memuaskan \\
\hline 3 & Jumlah siswa dalam satu kelas & $70,44 \%$ & Memuaskan \\
\hline 4 & Perlengkapan mengajar & $71,11 \%$ & Memuaskan \\
\hline 5 & $\begin{array}{l}\text { Pendapat tentang laboratorium } \\
\text { komputer. }\end{array}$ & $48,67 \%$ & $\begin{array}{l}\text { Kurang } \\
\text { memuaskan }\end{array}$ \\
\hline 6 & Pendapat tentang laboratorium ipa. & $61,67 \%$ & $\begin{array}{l}\text { Cukup } \\
\text { Memuaskan }\end{array}$ \\
\hline 7 & $\begin{array}{l}\text { Ketersediaan peralatan mengajar } \\
\text { dalam kelas. }\end{array}$ & $74,11 \%$ & Memuaskan \\
\hline 8 & $\begin{array}{l}\text { Pendapat tentang jumlah guru dan } \\
\text { tenaga kependidikan }\end{array}$ & $77,78 \%$ & Memuaskan \\
\hline 9 & $\begin{array}{l}\text { Ketersediaan buku literatur bacaan di } \\
\text { Perpustakaan }\end{array}$ & $74,67 \%$ & Memuaskan \\
\hline & Tingkat Kepuasan & $69,47 \%$ & $\begin{array}{l}\text { Cukup } \\
\text { Memuaskan }\end{array}$ \\
\hline
\end{tabular}

Dari tabel diatas dapat disimpulkan bahwa persepsi tingkat kepuasan wali siswa terhadap 
pelayanan madrasah binaan pada dimensi kualiatas Tangible adalah : a). Gedung Madrasah Tingkat kepuasan : Cukup Memuaskan dengan score 69,78 \%. b) Ruang Kelas terjaga kerapiannya : Memuaskan dengan score $77.00 \%$; c) Pendapat tentang Laboratorium Komputer : Kurang memuaskan dengan score 48,67 \%; d) Ketersediaan peralatan mengajar di kelas : Memuaskan dengan score $61.67 \%$; e) Laboratorium IPA : Cukup Memuaskan dengan score $70.44 \%$

Dari data tersebut nilai terendah untuk persepsi tingkat kepuasan orang tua terhadap pelayan madrasah binaan adalah tentang Laboratorium Komputer, dimana dari 13 madrasah yang diteliti baru 1 madrasah yang mempunyai laborarium Komputer yaitu MIN 6 Semarang. Sedangkan nilai tertinggi adalah mengenai jumlah guru dan tenaga kependidikan dianggap oleh orang tua siswa sudah ideal pada madrasah binaan dengan ketercapaian nilai 77,78 \% responden menyatakan Memuaskan.

Adapun secara keseluruhan tingkat kepuasan wali siswa terhadap pelayan Pendidikan di madrasah binaan pada dimensi Tangible (bukti fisik) secara umum dikategorikan Cukup Memuaskan dengan capaian nilai score $69,47 \%$.

\section{Persepsi Orang tua siswa terhadap kepuasan pelayanan Pendidikan di madarsah binaan pada Dimensi Realibilty (keandalan)}

Tabel 2. Persepsi Kepuasan orang tua pada Dimensi Realibility

\begin{tabular}{|c|c|c|c|}
\hline No. & Reliability ( Kehandalan) & & \\
\hline 1 & Ketepatan waktu jam mauk dan pulang & 77,22 & Memuaskan \\
\hline 2 & Guru yang tepat Waktu & 79,22 & Memuaskan \\
\hline 3 & $\begin{array}{l}\text { Fasilitas Penunjang } \\
\text { (Ibadah,Olahraga,Kantin,Urinoir) }\end{array}$ & 67,00 & $\begin{array}{l}\text { Cukup } \\
\text { Memuaskan }\end{array}$ \\
\hline 4 & Guru yang berdisiplin Tinggi & 72,67 & $\begin{array}{l}\text { Cukup } \\
\text { Memuaskan }\end{array}$ \\
\hline 5 & $\begin{array}{l}\text { Kesesuaian rencana dengan pelaksanaan } \\
\text { mengajar }\end{array}$ & 79,56 & Memuaskan \\
\hline 6 & Mengatasi Kesulitan belajar siswa & 77,00 & Memuaskan \\
\hline 7 & $\begin{array}{l}\text { Kemampuan Guru Menguasai Materi } \\
\text { Pendidikan }\end{array}$ & 70,44 & $\begin{array}{l}\text { Cukup } \\
\text { Memuaskan }\end{array}$ \\
\hline 8 & $\begin{array}{l}\text { Pengelolaan Kelas (tempat duduk, alat media } \\
\text { pembejaran) }\end{array}$ & 75,89 & Memuaskan \\
\hline 9 & Kerjasama lintas sektoral & 82,00 & Memuaskan \\
\hline & Tingkat Kepuasan & 75,67 & $\begin{array}{l}\text { Cukup } \\
\text { Memuaskan }\end{array}$ \\
\hline
\end{tabular}

Dari data tabel diatas dapat disimpulkan bahwa persepsi tingkat kepuasan wali siswa terhadap pelayanan madrasah binaan pada dimensi kualiatas Realibility (Kehandalan) adalah sebagai berikut : a) Ketepatan waktu jam masuk dan pulang sekolah : Memuaskan dengan score 77,22 \%; b) Kehadiran guru tepat waktu tingkat kepuasan mencapai 79,22\% yang berarti Memuaskan; c) Fasilitas Penunjang (Ibadah,Olah raga, Kantin, urinoir) hanya mendapat score 67,00\% berarti menurut persepsi orang tua hanya Cukup Memuaskan; d) Persepsi orang tua terhadap Guru yang berdisiplin tinggi dirasa Cukup Memuaskan dengan score 72,67 \%; Kesesuaian antara rencana pembelajaran dengan pelaksanaan mengajar guru dengan score nilai 79,56\% pada kategori Memuaskan; e) Guru mengatasi Kesulitan belajar siswa mencapai $77.00 \%$ dengan kategori Memuaskan; f) Kemampuan guru menguasai materi pembelajaran $70.44 \%$ kategori memuaskan; g) Kemampuan guru dalam mengelola kelas dengan score 75,89 \% Memuaskan; Sedangkan nilai tertinggi yang dianggap orang tua siswa adalah Kerjasama lintas sektoral dengan score 82,00 kategori Sangat Memuaskan. Adapun secara keseluruhan tingkat kepuasan wali siswa terhadap pelayan Pendidikan di madrasah binaan pada dimensi Realibilty (kehandalan) secara umum dikategorikan Cukup Memuaskan dalam layanan pendidkan dengan capaian nilai score 75,67\%. 
3. Persepsi Orang tua siswa terhadap kepuasan pelayanan Pendidikan di madarsah binaan pada Dimensi Reponsiveness (ketanggapan)

Tabel 3. Persepsi Kepuasan orang tua pada Dimensi Responseveness

\begin{tabular}{|l|l|r|l|}
\hline N0. & Dimensi Responseveness ( Ketanggapan) & & \\
\hline 1 & Keterbukaan guru menerima kritik & 70,33 & $\begin{array}{l}\text { Cuku } \\
\text { Memuaskan }\end{array}$ \\
\hline 2 & Masukan kepada guru & 63,56 & $\begin{array}{l}\text { Cuku } \\
\text { Memuaskan }\end{array}$ \\
\hline 3 & Tanggap terhadap persoalan siswa & 66,78 & Cuku \\
\hline 4 & $\begin{array}{l}\text { Memuaskan } \\
\text { belajar }\end{array}$ & 66,67 & Memuaskan \\
\hline 5 & Mengutaran persoalan pada guru & 76,00 & Cuku \\
\hline 6 & Memuaskan \\
\hline 7 & Penciptaan suasana kelas yang menarik & 71,33 & Cuku \\
\hline & Tingkat Kepuasan & 77,56 & $\begin{array}{l}\text { Cuku } \\
\text { Memuaskan }\end{array}$ \\
\hline
\end{tabular}

Dari tabel diatas dapat disimpulkan bahwa persepsi tingkat kepuasan wali siswa terhadap pelayanan madrasah binaan pada dimensi kualiatas Responsiveness adalah : a) Keterbukaan guru menerima kritik,70,33\% Cukup Memuaskan b) Masukan kepada guru 63,56 \% Cukup Memuaskan; c) Tanggap terhadap persoalan siswa 66,78 d) Membantu siswa yang mengalami kesulitan belajar 66,67 \% Cukup Memuaskan; f) Mengutarakan persoalan pada guru 76,00\% Cukup Memuaskan e) Memberikan bantuan terhadap persoalan murid 71,33 Cukup Memuaskan; g) Penciptaan suasana kelas yang menarik 77,56 C Memuaskan

Dari data tersebut nilai terendah untuk persepsi tingkat kepuasan orang tua terhadap pelayan madrasah binaan adalah tentang Masukan terhadap guru, dimana score tercapai hanya mencapai $63,35 \%$. Sedangkan nilai tertinggi adalah mengenai jumlah guru dan tenaga kependidikan dianggap oleh orang tua siswa sudah ideal pada madrasah binaan dengan ketercapaian nilai 77,56 \% responden menyatakan Memuaskan.

Adapun secara keseluruhan tingkat kepuasan wali siswa terhadap pelayan Pendidikan di madrasah binaan pada dimensi Responsiveness secara umum dikategorikan Cukup Memuaskan dengan capaian nilai score $70,32 \%$.

4. Persepsi Orang tua siswa terhadap kepuasan pelayanan Pendidikan di madarsah binaan pada Dimensi Assurance (jaminan dan kepastian)

Tabel 4. Persepsi Kepuasan orang tua pada Dimensi Assurance

\begin{tabular}{|l|l|r|l|}
\hline No. & Dimensi Responseveness ( Ketanggapan) & & \\
\hline 1 & Pendidikan etika sekolah & 76,78 & $\begin{array}{l}\text { Cukup } \\
\text { Memuaskan }\end{array}$ \\
\hline 2 & Pemeriksaan tugas secara teratur pada siswa & 71,56 & $\begin{array}{l}\text { Cukup } \\
\text { Memuaskan }\end{array}$ \\
\hline 3 & Guru berpenampilan rapi & 82,00 & Memuaskan \\
\hline 4 & Etika guru mengajar & 85,11 & Memuaskan \\
\hline 5 & Perilaku positif guru selama belajar & 87,22 & Memuaskan \\
\hline 6 & Kesalahan guru dalam mengajar & 78,78 & $\begin{array}{l}\text { Cukup } \\
\text { Memuaskan }\end{array}$ \\
\hline
\end{tabular}


Vol. 1 No. 3 Agustus 2021 e-ISSN : 2775-2593 | p-ISSN : 2775-2585

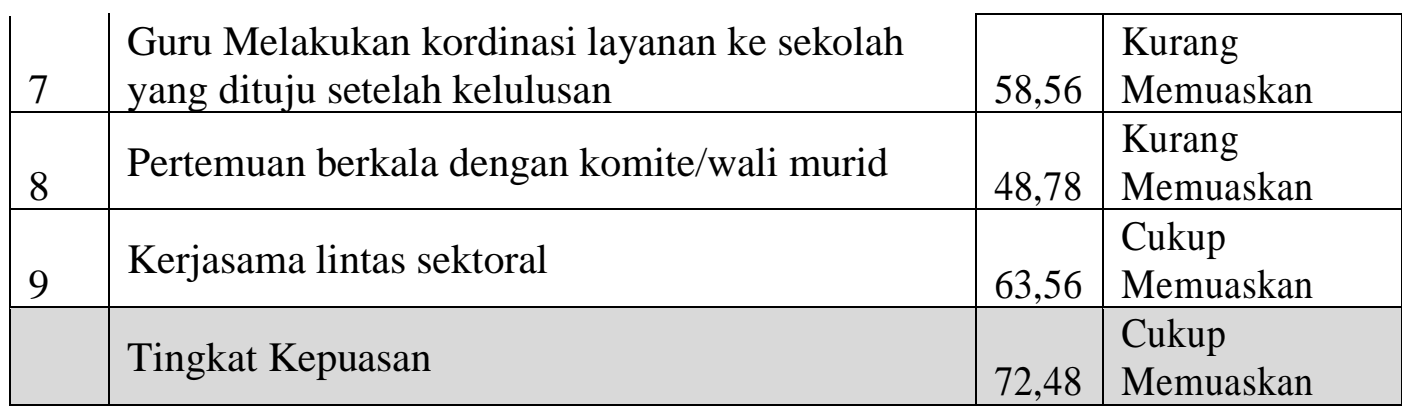

Dari tabel diatas dapat disimpulkan bahwa persepsi tingkat kepuasan wali siswa terhadap pelayanan madrasah binaan pada dimensi kualiatas Assurance adalah : a) Penidikan etika Tingkat kepuasan : Cukup Memuaskan dengan score 76,78 \%,; b) Pemeriksaan tugas secara teratur pada siswa score 71,56 \% dengan kategori sangat memuaskan; c) Guru berpenampilan rapi 82,00 kategori Memuaskan; d) Etika guru dalam mengajar 85,11 \% Memuaskan; e) Perilaku positif guru selama mengajar $87,78 \%$, f) Guru melakukan koordinasi layanan ke sekolah yang yang dituju siswa setelah kelulusan 58,56\% kurang memuaskan ; h) Pertemuan berkala dengan komite/wali 48,78 \% kurang memuaskan; i) Kerjasama lintas sektoral 63,56 \% Cukup Memuaskan .

Dari data tersebut nilai terendah untuk persepsi tingkat kepuasan orang tua terhadap pelayan madrasah binaan adalah tentang Laboratorium Komputer, dimana dari 13 madrasah yang diteliti baru 1 madrasah yang mempunyai laborarium Komputer yaitu MIN 6 Semarang. Sedangkan nilai tertinggi adalah mengenai jumlah guru dan tenaga kependidikan dianggap oleh orang tua siswa sudah ideal pada madrasah binaan dengan ketercapaian nilai 77,78 \% responden menyatakan Memuaskan.

Adapun secara keseluruhan tingkat kepuasan wali siswa terhadap pelayan Pendidikan di madrasah binaan pada dimensi Assurance secara umum dikategorikan Cukup Memuaskan dengan capaian nilai score $72,48 \%$.

\section{Persepsi Orang tua siswa terhadap kepuasan pelayanan Pendidikan di madarsah binaan pada Dimensi Empaty (empati)}

Tabel 5. Persepsi Kepuasan orang tua pada Dimensi Empathy

\begin{tabular}{|l|l|l|}
\hline \multicolumn{1}{|c|}{ Dimensi Responseveness ( Ketanggapan) } & & \\
\hline Ketersediaan layanan informasi & 72,00 & 3,56 \\
\hline Hubungan Komunikasi Guru dan Siswa & 86,33 & 4,27 \\
\hline Pembekalan Ujian & 78,00 & 3,86 \\
\hline Guru mengajar mudah difahami siswa & 79,78 & 3,95 \\
\hline Pendidikan Praktik Siswa & 56,44 & 2,79 \\
\hline Kebutuhan pembelajarn siswa tepenuhi & 64,00 & 3,16 \\
\hline Penghargaan bagi siswa yang berprestasi & 83,00 & 4,10 \\
\hline Posisi guru sebagai orang tua di sekolah & 86,44 & 4,27 \\
\hline Guru tidak pilh kasih & 83,00 & \\
\hline Tentang pemasaran siswa di tngkat berikutnya & 74,67 & 3,69 \\
\hline Tingkat Kepuasan & 76,37 & 33,66 \\
\hline
\end{tabular}

Dari data tersebut nilai terendah untuk persepsi tingkat kepuasan orang tua terhadap pelayan madrasah binaan adalah tentang Laboratorium Komputer, dimana dari 13 madrasah yang diteliti baru 1 madrasah yang mempunyai laborarium Komputer yaitu MIN 6 Semarang. Sedangkan nilai tertinggi adalah mengenai jumlah guru dan tenaga kependidikan dianggap oleh orang tua siswa sudah ideal pada madrasah binaan dengan ketercapaian nilai 77,78 \% responden menyatakan Memuaskan.

Adapun secara keseluruhan tingkat kepuasan wali siswa terhadap pelayan Pendidikan di madrasah binaan pada dimensi Empathy secara umum dikategorikan Cukup Memuaskan dengan 


\section{EDUCATIONAL : Jurnal Inovasi Pendidikan dan Pengajaran \\ Vol. 1 No. 3 Agustus 2021 e-ISSN : 2775-2593 | p-ISSN : 2775-2585}

capaian nilai score $76,37 \%$.

Dari tabel-tabel diatas dapat disimpulkan bahwa persepsi tingkat kepuasan Orang tua wali siswa terhadap pelayanan Pendidikan madrasah binaan Kec. Bringin Kab. Semarang yang meliputi 5 Dimensi : Tangible (bukti fisik), Realibility (keandalan) 75,67 \% Cukup Memuaskan, Responsiveness (ketanggapan), Assurance (jaminan dan kepastian), Empathy (empati) terhadap kepuasan orang tua (wali murid).

Hal itu berarti hasil penelitian ini mendukung teori yang dijadikan kerangka dasar penelitian, sesuai dengan teori yang menyebutkan bahwa kepuasan mempengaruhi persepsi terhadap kualitas layanan. Menurut Pujawa (2010), kualitas pelayanan sebagai hasil persepsi dan perbandingan antara harapan pelanggan dengan kinerja aktual pelayanan yang terdapat dua faktor utama yang mempengaruhi kualitas jasa, yaitu pengalaman yang diharapkan dan pelayanan yang diterima.

Pada penelitian yang dilakukan oleh Agatha Reni Ambarwati (2009) dengan penelitian yang berjudul "Kepuasan Siswa Terhadap Kualitas Pelayanan Pendidikan Di SMP Negeri 2 Moyudan". Dalam penelitian ini mendeskripsikan tentang kepuasan siswa terhadap kualitas pelayanan pendidikan di SMP Negeri 2 Moyudan. Kepuasan siswa tehadap kualitas pelayanan pendidikan dalam penelitian ini meliputi aspek reliability, responsivenness, assurance, empathy dan tangible dengan membandingkan antara harapan dan kenyataan yang melibatkan aspek kognisi dan afeksi.

\section{KESIMPULAN}

Kepuasan orang tua siuswa memiliki kaitan yang sangat erat dengan harapan orang tua siswa atas kualitas pelayanan yang ditawarkan oleh madrasah. Kepuasan orang tua siswa tidak ditentukan semata-semata oleh pengajaran iswa dan pengalaman belajar iswa, melainkan juga ditentukan dengan pengalaman siswa secara berpengaruh dalam menentukan kepuasan orang tua siswa terhadap sekolah Apabila Madrasah mampu memenuhi kelima dimensi ter

Dengan pengukuran kulaitas pelayanan pendidikan madrasah binaan di kecamatan Bringin Kabupaten Semarang dengan model SERVQUAL ( Service Quality) yang terdiri dari hasil penelitian 5 Dimensi pengukuran. Apabila madrasah mampu memenuhi kelima kriteria dimensi tersebut bahkan melebihi harapan siswa/orang tua akan merasa puas atas pelayanan pendidikan Madrasah, maka diharapkan madrasah mampu memenuhi tuntutan tersebut untuk membangun citra tentang kualiats layanan serta loyalitas orang tua untuk menyekolahkan pada lembaga pendidikan Madrasah tersebut.

Hasil dari penelitian tentang persepsi tingkat kepuasan orang tua terhadap pelayanan pendidikan di madrasah Kecamatan Bringin Kabupaten Semarang menunjukkan sejauh mana penilaian atas layanan pendidikan madrasah yang selama ini dirasakan oleh orang tua tua siswa tentang kualitas layanan pendidikan yang diterimanya pada 5 Dimensi pengukuran: 1) Tangible (Bukti Fisik) denagn score nilai 69,47 \% dalam kategori persepsi orang tua Cukup Memuaskan; 2) Realibilty (Kehandalan) 70,32 dengan kategori Cukup Memuaskan; , Responsiveness (Responsif), Assurance (jaminan) 72,48 \%, Empaty (Empati). 76,37\% dengan kategori Cukup Memuaskan.

\section{DAFTAR PUSTAKA}

Agatha Reni Ambarwati. (2009).Kepuasan Siswa Terhadap Kualitas Pelayanan Pendidikan Di SMP Negeri 2 Moyudan. Skripsi. Universitas Sanata Dharma

Ali, A. (2016). Pengaruh Struktur Modal terhadap Profitabilitas pada PerusahaanTelekomunikasi. Jurnal Ilmu dan Riset Manajemen, Vol. 4, hlm: 1-20.

Asaputra Kevin dan Handoyo Wibisono. (2016). Pengaruh Institusional Structures, Trust InSeller, Seller Past Performance, Perceived Risk, dan Customer Satisfaction Terhadap Transaction Intentions Di Situs Kaskus. Modus Journal. Vol.28, No.1, hal :53-70.

Bukhori Alma Dan Ratih Hurriyanti. (2008). Manajemen Corporate Dan Strategi Pemasaran Jasa Pendidikan Fokus Pada Mutu Dan Layanan Prima. Bandung: Alfabeta

Donnelly, James H., James L. Gibson dan John M. Ivancevich. (2003). Fundamentals of Management. Texas : Business Publication

E. Mulyasa. (2011). Manajemen \& Kepemimpinan Kepala Sekolah. Jakarta : Bumi Aksara 
Fandi Tjiptono. (2001). Kualitas Jasa: Pengukuran, Keterbatasan dan Implikasi Manajerial, majalah Manajemen Usahawan Indonesia. Jakarta

I Nyoman Pujawan. (2010). Supply Chain Management, Ed II. Surabaya: Guna Widya

Irma Fanita, dkk. (2013). Persepsi Mahasiswa Terhadap Kualitas Layanan Pendidikan Akademi Manajemen Informatika dan Komputer Indonesia (AMIKI) Banda Aceh. JURNAL EKONOMI MANAJEMEN DAN BISNIS, Vol 1(1)

Nana Herdiyana, Abdurrahman. (2015). Manajemen Strategi Pemasaran. Bandung: Pustaka Setia

Parasuraman,A.,Zeithaml,V.\& Berry,L. (2000). Communication and control processes in the delivery of service quality. Journal of marketing,52,35-48

Peraturan Menteri Pendidikan Nasional Republik Indonesia Nomor 23 tahun 2013 tentang standar layanan minimal di sekolah kabupaten/kota

Ronita Uli Sari Sianipar. (2018). Pengaruh Kualitas Pelayanan Customer Relations Terhadap Kepuasan Pengunjung Di Mal SKA Pekanbaru. Pekanbaru:Universitas Riau, Vol. 5 No.1, hlm. 6

Rusdiana.(2015). Pengelolaan Pendidikan. CV. Pustaka Setia: Bandung

Sinambela, Lijan Poltak.et al. (2008). Reformasi Pelayan Publik , "Teori, Kebiajakn dan Reformas" Jakarta: Bumi Aksara. 